\title{
First Record of Six Marine Ciliate Species of Genus Strombidium (Ciliophora: Spirotricha: Oligotrichia) from Korea with Ecological Notes
}

\author{
Eun Sun Lee ${ }^{1}$, Dapeng $\mathrm{Xu}^{1}$, Mann Kyoon Shin ${ }^{2}$, Young-Ok Kim ${ }^{1, *}$ \\ ${ }^{1}$ Korea Institute of Ocean Science and Technology (KIOST), Geoje 656-830, Korea \\ ${ }^{2}$ Department of Biological Science, University of Ulsan, Ulsan 680-749, Korea
}

\begin{abstract}
To supply the morphological and ecological information of oligotrich ciliates in Korea, water samples were seasonally collected in Gwangyang Bay and Jinhae Bay from August, 2010 to February, 2012 and processed by quantitative protargol staining method. As a result, six species belonging to the genus Strombidium Claparède and Lachmann, 1859 are identified: Strombidium emergens Kahl, 1932; S. dalum Lynn et al., 1988; S. epidemum Lynn et al., 1988; S. tressum Lynn et al., 1988; S. bilobum Lynn and Gilron, 1993; S. pollostomum Lynn and Gilron, 1993. These six species were newly reported from Korean coastal waters. Strombidium emergens is a middle sized Strombidium (20-50 $\mu \mathrm{m}$ in length) and has open and deep oral groove to girdle portion. Strombidium dalum is a small sized Strombidium ( $\leq 20 \mu \mathrm{m}$ in length), that has torch-like spiral anterior membranelles and an inverted triangles-shaped macronucleus on the posterior pole. The small sized S. epidemum has conspicuous trichites surrounding the girdle portion and ventral membranelles distinctly separated from anterior membranelles. The small sized S. tressum has torch-like spiral and extremely long trichites among the cilia of anterior membranelles. The middle sized S. bilobum has a bilobed macronucleus. Strombidium pollostomum is also a small sized Strombidium but its ventral membranelles are continuously connected with anterior membranelles. The five species except S. emergens occurred frequently over the wide range of water temperatures and salinities.
\end{abstract}

Keywords: Strombidium, oligotrich ciliates, coastal waters, quantitative protargol staining, ecology, morphology

\section{INTRODUCTION}

In the marine ecosystem, ciliates have been recognized as a dominant group in microzooplankton and known to serve as an effective link between the microbial loop and metazoan food web (Maeda and Carey, 1985; Maeda, 1986; Agatha, 2011). Recent investigations show that aloricate oligotrich ciliates occur in high numbers and consume significant quantities of autotrophic and heterotrophic microbial production (Quevedo and Anadón, 2000; Fileman and Leakey, 2005; Bojanic et al., 2006). The oligotrichs have been recorded with Bütschli's classification scheme since 1889 and about 300 species have been reported (excluding tintinnids) up to the present (Agatha, 2004a; Agatha and Strüder-Kypke, 2007; $\mathrm{Xu}$ et al., 2009). However, the taxonomic composition and ecological characteristics of the oligotrichs in Korean coastal waters are poorly known. To date, only 18 aloricate oligotrichs were described (only about $6 \%$ of recorded species in the world) (Suzuki and Han, 2000; Jeong et al., 2004; Moon et al., 2004; Kim et al., 2005, 2008, 2010; Ma and Choi, 2005; Lee et al., 2006, 2011).

The genus Strombidium Claparède and Lachmann, 1859 has well known as a cosmopolitan and diverse group within the oligotrichs. The characteristics of these species are as follows: anterior membranelles and ventral membranelles encircled on the oral region and not forming a complete circle, polysaccharide plates (or platelets) covered posterior half of body, horizontal girdle kinety and longitudinal ventral kinety, trichites forming a characteristic band. About 80 species have been described up to now, but many species still need to be studied due to the lack of morphologic information that can be used to identify the species (Fauré-Fremiet, 1932; Kahl,

\footnotetext{
(c) This is an Open Access article distributed under the terms of the Creative Commons Attribution Non-Commercial License (http://creativecommons.org/ licenses/by-nc/3.0/) which permits unrestricted non-commercial use, distribution, and reproduction in any medium, provided the original work is properly cited.

pISSN 2234-6953 eISSN 2234-8190
}

*To whom correspondence should be addressed

Tel: 82-55-639-8520, Fax: 82-55-639-8509

E-mail: yokim@kiost.ac 


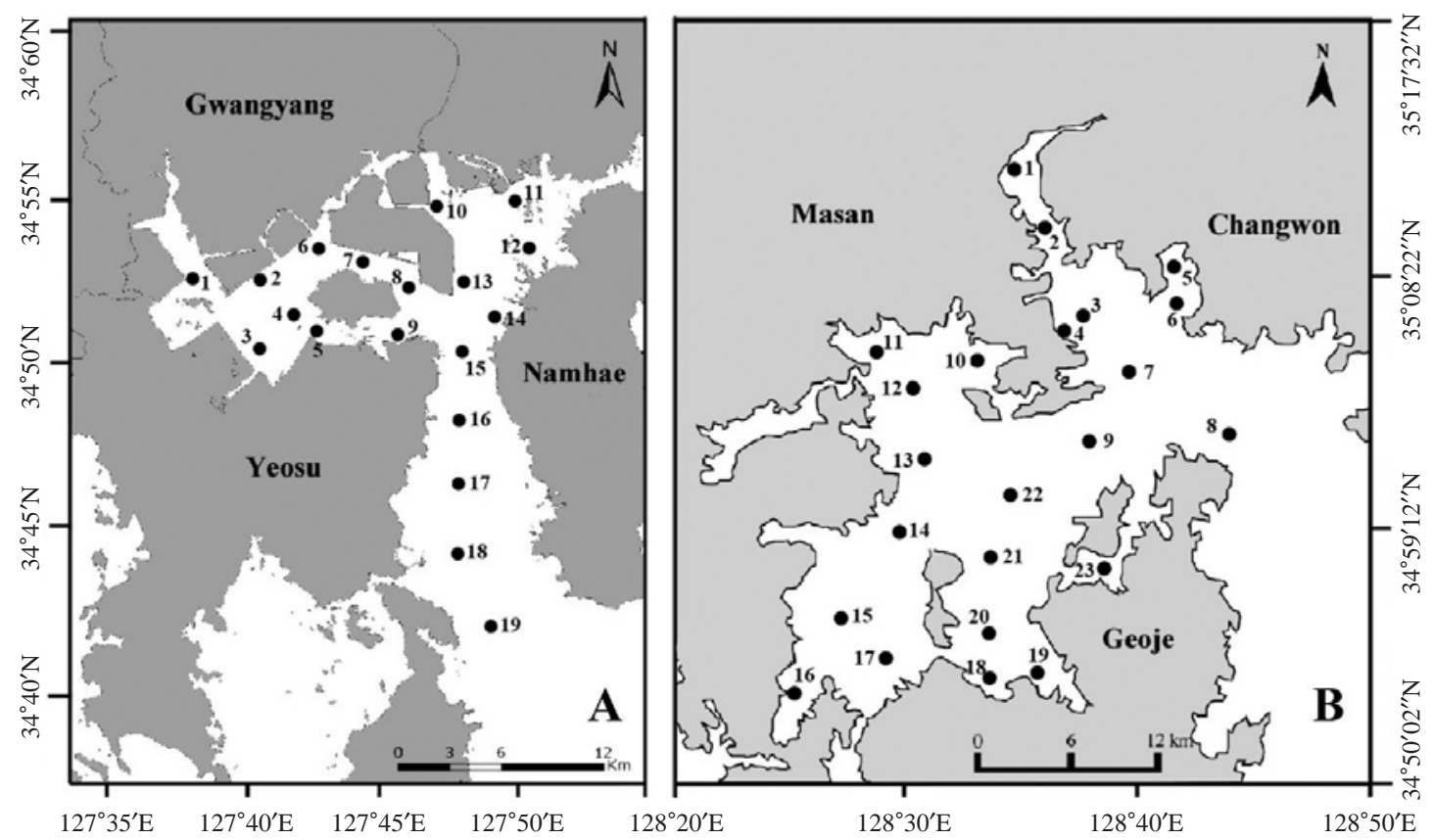

Fig. 1. Sampling sites from Gwangyang Bay (A, 19 sites) and Jinhae Bay (B, 23 sites) in the southern coastal areas of Korea.

1932; Maeda and Carey, 1985; Lynn et al., 1988; Montagnes et al., 1988, 1990, 2002; Montagnes and Lynn, 1991; Petz and Foissner, 1992; Lynn and Gilron, 1993; Martin and Montagnes, 1993; Petz et al., 1995; Agatha and Riedel-Lorjé, 1997; Kim and Taniguchi, 1997; Montagnes and Humphrey, 1998; Song and Bradbury, 1998; Lei et al., 1999; Song et al., 2000; Agatha, 2003; Granda and Montagnes, 2003; Modeo et al., 2003; Agatha, 2004b; Agatha et al., 2005; Xu et al., 2006, 2007, 2009; McManus et al., 2010; Liu et al., 2011). Several studies have described with their ecological data concerning the occurrences at different water temperatures and salinities, as well as the morphologic data. According to their studies, Strombidium antarcticum occurred in water temperature of up to $-4.5^{\circ} \mathrm{C}$ and salinity of up to $60 \mathrm{psu}$ (practical salinity units). Strombidium conicum was recorded that the abundance is up to 123,600 cells per liter within the range of water temperatures of $4-12^{\circ} \mathrm{C}$ and salinities of $12-24 \mathrm{psu}$. The maximum abundance of Strombidium lingulum forming the redtide was recorded up to $1.5 \times 10^{6}$ cells per liter with a water temperature of $14^{\circ} \mathrm{C}$ and salinity of 31-32 psu (Petz et al., 1995; Agatha and Riedel-Lorjé, 1997; Montagnes and Humphrey, 1998).

As a serial report on the taxonomical study of oligotrich ciliates in Korean coastal waters, we describe morphologically six Strombidium species collected from Gwangyang Bay and Jinhae Bay in the southern coastal area and provide also the ecological data of these species.

\section{MATERIALS AND METHODS}

\section{Water sampling}

Ciliate plankton was investigated seasonally in Gwangyang Bay (19 sites in Fig. 1A) and Jinhae Bay (23 sites in Fig. 1B) from August 2010 to February 2012 (August and November in 2010; February, May, August, and November in 2011; February in 2012). To collect ciliate cells, surface sea water was sampled by a bucket and fixed using Bouin's solution in the field (at final concentration $10 \%$, v/v). Water temperature and salinity were measured in situ using electronic conductivity-temperature-depth sensor (IDRONUT Ocean Seven 316; IDRONUT, Brugherio, Italy).

\section{Cell identification and counting}

The water samples fixed were analyzed by the quantitative protargol stain (QPS), following the protocol of Montagnes and Lynn (1993). In brief, $50 \mathrm{~mL}$ of fixed water samples were filtered through $0.8 \mu \mathrm{m}$ in pore size membrane filters (Startorius Stedin Biotech, Goettingen, Germany) and filtered samples were covered with a thin layer of agar to avoid the loss of cells during the next step of preparation. Then, the membranes were bleached, protargol impregnated and mounted. Under a light-field microscope (Zeiss Axioskop II; Carl Ziess, Jena, Germany), the protargol impregnated cells were identified and counted at the magnification of 400-1,600 $\times$. 


\section{Terminology}

The terminology and classification for the ciliate taxonomy are according to Montagnes and Lynn (1991) and Agatha (2004a) respectively.

\section{RESULTS AND DISCUSSION}

Class Oligotrichea Bütschli, 1889

Subclass Oligotrichia Bütschli, 1889

Order Oligotrichida Bütschli, 1889

Family Strombidiidae Fauré-Fremiet, 1970

1*Genus Strombidium Claparède and Lachmann, 1859

${ }^{2 *}$ Strombidum emergens (Leegaard, 1915) Kahl, 1932

(Table 1, Figs. 2, 3)

Strombidium emergens Kahl, 1932: 503, fig. 13; Pettigrosso, 2003: 123, fig. 10.

Strombidium sulcatum Lynn et al., 1988: 273, figs. 4E, 6J. Strombidium ventropinnum Martin and Montagnes, 1993: 541, figs. 7A-E, 8A, B.

Diagnosis. Body long cone-shaped; deep and open oral groove on ventral surface, extending posteriorly to about halfway down the cell; size $22-27 \mu \mathrm{m}$ in length and $11-17 \mu \mathrm{m}$ in width after protargol impregnation; anterior membranelles composed of 13-15 polykinetids; ventral membranelles distinctly separated from anterior membranelles, composed of 8-9 polykinetids; girdle kinety completely surrounding the cell, composed of 34-42 dikinetids; ventral kinety composed of 9-11 dikinetids; one heart-shaped macronucleus, $6 \times 5 \mu \mathrm{m}$ in size; one spherical micronucleus, $1-2 \mu \mathrm{m}$ in diameter.

Morphological description of the Korean population. Long cone-shaped body, cylindrical anterior portion and conical posterior portion, no apical protrusion detected. $\mathrm{Nu}-$ merous trichites inserting above girdle and extending to posterior of body, not in bundles (Fig. 2F). Distended cell surface covered from girdle to posterior pole of the cell. No polygonal surface recognizable in protargol impregnated specimen (Fig. 2C-E). Size 22-27 $\mu \mathrm{m}$ in length and $11-17 \mu \mathrm{m}$ in width after protargol impregnation (average $24.5 \times 14.1 \mu \mathrm{m}$, $\mathrm{n}=12$ ).

Oral groove relatively deep and open on ventral surface, extending to about halfway down the cell (2/5-1/2 of the body). Anterior membranelles distinctly separated from ventral membranelles. Bases of anterior membranelles connected by fibres system, the cilia of anterior membranelles torchlike spiral, composed of 13-15 polykinetids (average 14 polykinetids, $\mathrm{n}=12$ ). Ventral membranelles lying on the left wall of oral groove that forms a sunken pit, composed of 8-9 polykinetids (average 9 polykinetids, $\mathrm{n}=12$ ). No endoral membrane detected (Fig. 2A-C).

Somatic ciliature composed of girdle kinety and ventral kinety, no extra kinety detected. Girdle kinety, horizontal and equatorial, completely surrounding the cell and composed of 34-42 dikinetids (average 38 dikinetids, $n=7$ ). Vertical ventral kinety, slightly tilted toward the right, composed of 9-11 dikinetids (average 10 dikinetids, $\mathrm{n}=2$ ).

One macronucleus, heart-shaped, located below oral groove and contained many spherical nucleoli, 4-8 $\mu \mathrm{m}$ in length and $4-6 \mu \mathrm{m}$ in broad width (average $6.2 \times 5.1 \mu \mathrm{m}, \mathrm{n}=12$ ). One micronucleus attached on macronucleus, $1-2 \mu \mathrm{m}$ in diameter. Occurrence and ecological characteristics. The Korean population was collected from Jinhae Bay (August, 2011) and Gwangyang Bay (November, 2011) recording the water temperatures of $22-23^{\circ} \mathrm{C}$ and $15^{\circ} \mathrm{C}$ and the salinities of $27-28$ psu and 31 psu respectively. A maximum abundance (700 cells/L) was observed in August, 2011 from Jinhae Bay (Fig. $3)$.

The Argentina population was collected from Puerto Cuatreros where the water temperature and salinity were $9-12^{\circ} \mathrm{C}$ and 30-33 psu respectively (Pettigrosso, 2003).

Comparison with other populations. Strombidium emergens was recorded by Leegaard (1915), Kahl (1932), Lynn et al. (1988), Petz et al. (1995), and Pettigrosso (2003). Leegaard (1915) first described this species as Laboea emergens. Unfortunately, the morphological informations decribed by Leegaard (1915) and Kahl (1932) were not enough to identify S. emergens.

This population is similar to Strombidium sulcatum which was recorded from Isles of Shoals (Gulf of Maine, Atlantic population) by Lynn et al. (1988), but the species was transferred to S. emergens by Montagnes et al. (1990). More recently, Pettigrosso also recorded the Argentinian population of S. emergens. These three populations-Korean, Argentinian and Atlantic populations-have almost overlapped morphometric data except for the shape of macronucleus.

Compared with the Antarctic population described by Petz et al. (1995), the two populations have many differences; the cell size is considerably smaller $(22-27 \times 11-17 \mu \mathrm{m}$ in the Korean population vs. $90 \times 49-52 \mu \mathrm{m}$ in the Antarctica population), a smaller number of ventral kinety (9-11 dikinetids vs. 20 dikinetids), and more ventral membranelles (8-9 polykinetids vs. 4-5 polykinetids). As well, the ventral membranelles of the Antarctica population is inconspicuous (vs. extending to girdle portion in the Korea population), continuous with anterior membranelles (vs. conspicuously separated from anterior membranelles in the Korean population), 
Table 1. Morphometrical characterization of Strombidium emergens (S.em), S. dalum (S.d.), S. epidemum (S.ep.), S. tressum (S.t.), S. bilobum (S.b.), S. pollostomum (S.p.)

\begin{tabular}{|c|c|c|c|c|c|c|c|c|}
\hline Characteristics & Species & Min & Max & Mean & SD & SE & $\mathrm{CV}$ & $\mathrm{N}$ \\
\hline \multirow[t]{6}{*}{ Cell length } & S.em. & 21.5 & 27.1 & 24.5 & 1.9 & 0.6 & 7.8 & 12 \\
\hline & S.d. & 12.5 & 18.8 & 14.9 & 1.7 & 0.5 & 11.3 & 14 \\
\hline & S.ep. & 12.2 & 20.4 & 14.6 & 2.1 & 0.5 & 14.2 & 17 \\
\hline & S.t. & 12.6 & 21.3 & 15.1 & 2.2 & 0.5 & 14.7 & 22 \\
\hline & S.b. & 30.9 & 36.3 & 33.3 & 1.6 & 0.4 & 4.8 & 15 \\
\hline & S.p. & 11.6 & 19.1 & 15.1 & 2.4 & 0.5 & 15.8 & 22 \\
\hline \multirow[t]{6}{*}{ Cell width } & S.em. & 10.9 & 16.9 & 14.1 & 1.6 & 0.5 & 11.4 & 12 \\
\hline & S.d. & 7.0 & 10.2 & 9.2 & 0.9 & 0.3 & 10.2 & 14 \\
\hline & S.ep. & 10.1 & 16.7 & 12.0 & 1.5 & 0.4 & 12.9 & 17 \\
\hline & S.t. & 9.9 & 15.0 & 12.4 & 1.4 & 0.3 & 11.3 & 22 \\
\hline & S.b. & 14.2 & 20.6 & 17.8 & 2.1 & 0.6 & 12.1 & 15 \\
\hline & S.p. & 7.5 & 14.5 & 10.7 & 1.8 & 0.4 & 16.7 & 22 \\
\hline \multirow[t]{6}{*}{ Cell length : width, ratio } & S.em. & 1.5 & 2.1 & 1.8 & 0.2 & 0.1 & 10.4 & 12 \\
\hline & S.d. & 1.4 & 2.2 & 1.6 & 0.3 & 0.1 & 15.3 & 14 \\
\hline & S.ep. & 1.1 & 1.3 & 1.2 & 0.1 & 0.0 & 5.2 & 17 \\
\hline & S.t. & 1.1 & 1.4 & 1.2 & 0.1 & 0.0 & 7.1 & 22 \\
\hline & S.b. & 1.7 & 2.7 & 2.0 & 0.3 & 0.1 & 16.2 & 15 \\
\hline & S.p. & 1.1 & 1.7 & 1.4 & 0.1 & 0.0 & 8.5 & 22 \\
\hline Oral width & S.b. & 19.4 & 23.8 & 22.2 & 2.4 & 1.4 & 11.0 & 3 \\
\hline Oral groove length & S.em. & 9.2 & 12.8 & 11.3 & 0.9 & 0.3 & 8.3 & 12 \\
\hline \multirow[t]{2}{*}{ GK width } & S.b. & 12.4 & 22.6 & 16.6 & 2.6 & 0.7 & 15.5 & 15 \\
\hline & S.p. & 8.3 & 10.2 & 9.3 & 0.7 & 0.3 & 7.2 & 6 \\
\hline Cell length : GK width, ratio & S.b. & 1.5 & 2.7 & 2.0 & 0.3 & 0.1 & 15.7 & 15 \\
\hline \multirow[t]{6}{*}{ AM, number } & S.em. & 13.0 & 15.0 & 13.8 & 0.7 & 0.2 & 5.0 & 12 \\
\hline & S.d. & 13.0 & 15.0 & 14.0 & 0.7 & 0.2 & 4.9 & 14 \\
\hline & S.ep. & 12.0 & 15.0 & 13.2 & 1.0 & 0.2 & 7.3 & 17 \\
\hline & S.t. & 13.0 & 15.0 & 14.1 & 0.9 & 0.2 & 6.5 & 22 \\
\hline & S.b. & 14.0 & 17.0 & 14.8 & 1.0 & 0.3 & 6.6 & 11 \\
\hline & S.p. & 12.0 & 16.0 & 13.6 & 1.0 & 0.2 & 7.5 & 19 \\
\hline \multirow[t]{6}{*}{ VM, number } & S.em. & 8.0 & 9.0 & 8.2 & 0.4 & 0.1 & 4.8 & 12 \\
\hline & S.d. & 6.0 & 9.0 & 7.3 & 1.1 & 0.3 & 14.6 & 12 \\
\hline & S.ep. & 5.0 & 7.0 & 5.9 & 0.5 & 0.1 & 8.2 & 17 \\
\hline & S.t. & 5.0 & 8.0 & 6.4 & 0.7 & 0.2 & 10.9 & 18 \\
\hline & S.b. & 9.0 & 13.0 & 10.5 & 1.4 & 0.5 & 13.5 & 8 \\
\hline & S.p. & 4.0 & 6.0 & 5.3 & 0.7 & 0.2 & 14.1 & 19 \\
\hline \multirow[t]{5}{*}{ GK, number } & S.em. & 34.0 & 42.0 & 3.8 & 2.8 & 1.1 & 7.4 & 7 \\
\hline & S.d. & 20.0 & 24.0 & 22.0 & 1.6 & 0.8 & 7.4 & 4 \\
\hline & S.t. & 30.0 & 38.0 & 33.0 & 3.3 & 1.3 & 10.0 & 6 \\
\hline & S.b. & 36.0 & 40.0 & 38.0 & 2.0 & 1.2 & 5.3 & 3 \\
\hline & S.p. & 14.0 & 16.0 & 15.0 & 1.4 & 1.0 & 9.4 & 2 \\
\hline \multirow[t]{6}{*}{ VK, number } & S.em. & 9.0 & 11.0 & 10.0 & 1.4 & 1.0 & 14.1 & 2 \\
\hline & S.d. & 4.0 & 7.0 & 5.2 & 1.3 & 0.6 & 25.1 & 5 \\
\hline & S.ep. & 4.0 & 4.0 & 4.0 & - & - & - & 1 \\
\hline & S.t. & 8.0 & 11.0 & 8.8 & 0.9 & 0.3 & 9.9 & 11 \\
\hline & S.b. & 4.0 & 6.0 & 4.8 & 0.8 & 0.3 & 17.4 & 9 \\
\hline & S.p. & 3.0 & 5.0 & 3.9 & 0.6 & 0.2 & 16.5 & 8 \\
\hline \multirow[t]{6}{*}{ Ma, number } & S.em. & 1.0 & 1.0 & 1.0 & 0.0 & 0.0 & 0.0 & 12 \\
\hline & S.d. & 1.0 & 1.0 & 1.0 & 0.0 & 0.0 & 0.0 & 12 \\
\hline & S.ep. & 1.0 & 1.0 & 1.0 & 0.0 & 0.0 & 0.0 & 17 \\
\hline & S.t. & 1.0 & 1.0 & 1.0 & 0.0 & 0.0 & 0.0 & 11 \\
\hline & S.b. & 2.0 & 2.0 & 2.0 & 0.0 & 0.0 & 0.0 & 15 \\
\hline & S.p. & 1.0 & 1.0 & 1.0 & 0.0 & 0.0 & 0.0 & 20 \\
\hline \multirow[t]{6}{*}{ Ma, length1 } & S.em. & 4.4 & 7.6 & 6.2 & 0.8 & 0.2 & 13.0 & 12 \\
\hline & S.d. & 3.5 & 6.0 & 4.7 & 0.7 & 0.2 & 14.2 & 12 \\
\hline & S.ep. & 4.3 & 11.1 & 6.1 & 1.8 & 0.4 & 28.6 & 17 \\
\hline & S.t. & 5.1 & 7.3 & 6.0 & 0.6 & 0.1 & 9.9 & 21 \\
\hline & S.b. & 6.0 & 11.1 & 8.8 & 1.2 & 0.3 & 13.6 & 14 \\
\hline & S.p. & 4.1 & 8.7 & 6.0 & 1.4 & 0.3 & 22.9 & 20 \\
\hline Ma, length2 & s.b. & 6.5 & 10.6 & 8.0 & 1.2 & 0.3 & 15.2 & 13 \\
\hline
\end{tabular}


Table 1. Continued

\begin{tabular}{|c|c|c|c|c|c|c|c|c|}
\hline Characteristics & Species & Min & Max & Mean & SD & SE & $\mathrm{CV}$ & $\mathrm{N}$ \\
\hline \multirow[t]{6}{*}{ Ma, width1 } & S.em. & 4.2 & 5.8 & 5.1 & 0.5 & 0.1 & 8.9 & 12 \\
\hline & S.d. & 2.2 & 4.5 & 3.6 & 0.7 & 0.2 & 19.4 & 12 \\
\hline & S.ep. & 3.4 & 6.2 & 4.2 & 0.8 & 0.2 & 18.4 & 17 \\
\hline & S.t. & 1.3 & 6.0 & 4.6 & 1.0 & 0.2 & 22.4 & 21 \\
\hline & S.b. & 3.6 & 7.9 & 4.9 & 1.1 & 0.3 & 21.7 & 14 \\
\hline & S.p. & 3.4 & 7.3 & 4.9 & 1.2 & 0.3 & 25.4 & 20 \\
\hline Ma, width2 & S.b. & 3.5 & 7.4 & 5.0 & 1.2 & 0.3 & 24.5 & 13 \\
\hline \multirow[t]{5}{*}{$\mathrm{Mi}$, number } & S.em. & 1.0 & 1.0 & 1.0 & 0.0 & 0.0 & 0.0 & 4 \\
\hline & S.d. & 1.0 & 1.0 & 1.0 & 0.0 & 0.0 & 0.0 & 6 \\
\hline & S.ep. & 1.0 & 1.0 & 1.0 & 0.0 & 0.0 & 0.0 & 7 \\
\hline & S.t. & 1.0 & 1.0 & 1.0 & 0.0 & 0.0 & 0.0 & 4 \\
\hline & S.p. & 1.0 & 1.0 & 1.0 & 0.0 & 0.0 & 0.0 & 5 \\
\hline \multirow[t]{5}{*}{ Mi, diameter } & S.em. & 1.1 & 2.0 & 1.5 & 0.4 & 0.2 & 26.1 & 4 \\
\hline & S.d. & 0.9 & 1.8 & 1.3 & 0.3 & 0.1 & 24.6 & 6 \\
\hline & S.ep. & 0.9 & 1.8 & 1.3 & 0.4 & 0.1 & 31.4 & 7 \\
\hline & S.t. & 0.8 & 1.5 & 1.0 & 0.3 & 0.2 & 30.0 & 4 \\
\hline & S.p. & 1.0 & 1.3 & 1.1 & 0.1 & 0.1 & 10.8 & 5 \\
\hline \multirow[t]{3}{*}{ A globular drop, diameter } & S.d. & 1.0 & 1.3 & 1.1 & 0.2 & 0.1 & 14.1 & 3 \\
\hline & S.ep. & 1.1 & 2.1 & 1.4 & 0.3 & 0.1 & 18.9 & 10 \\
\hline & S.p. & 0.9 & 1.2 & 1.1 & 0.1 & 0.0 & 10.4 & 10 \\
\hline \multirow{6}{*}{ Oral to posterior, length } & S.em. & 9.9 & 15.5 & 13.2 & 1.9 & 0.6 & 14.6 & 12 \\
\hline & S.d. & 6.4 & 12.6 & 9.1 & 1.7 & 0.5 & 18.8 & 14 \\
\hline & S.ep. & 6.4 & 10.1 & 7.9 & 0.9 & 0.2 & 12.0 & 15 \\
\hline & S.t. & 7.6 & 12.9 & 10.1 & 1.7 & 0.4 & 16.4 & 20 \\
\hline & S.b. & 20.8 & 26.6 & 23.8 & 1.6 & 0.4 & 6.8 & 15 \\
\hline & S.p. & 6.6 & 13.1 & 10.0 & 2.1 & 0.5 & 20.5 & 18 \\
\hline \multirow[t]{2}{*}{ GK to posterior, length } & S.b. & 12.2 & 15.3 & 13.2 & 1.0 & 0.3 & 7.4 & 11 \\
\hline & S.p. & 5.3 & 6.8 & 6.1 & 1.0 & 0.7 & 16.7 & 2 \\
\hline $\mathrm{T}$, length & S.ep. & 2.1 & 7.4 & 3.7 & 1.6 & 0.6 & 43.0 & 8 \\
\hline
\end{tabular}

Data based on protargol impregnated and randomly selected specimens. Measurements in $\mu \mathrm{m}$.

Min, minimum; Max, maximum; Mean, arithmetic mean; SD, standard deviation; SE, standard error; CV, coefficient of variation; N, number of specimen; AM, anterior membranelles; VM, ventral membranelles; GK, girdle kinety; VK, ventral kinety; Ma, macronucleus; Mi, micronucleus; T, trichites.

and covered by cytoplasmic wall (vs. open on ventral side).

Strombidium ventropinnum recorded as a new species by Martin and Montagnes (1993) is also very similar to this population. However, S. ventropinnum has more dikinetids of ventral kinety (10-14 vs. 9-11 in the Korean population of $S$. emergens) and one ovoid macronucleus (vs. heart-shaped). Morphologically, the Korean population is more similar to $S$. ventropinnum rather than the Antarctica population of $S$. emergens in protargol impregnation.

\section{$1 *$ Strombidium dalum Lynn, Montagnes and Small, 1988 (Table 1, Figs. 4, 5)}

Strombidium dalum Lynn et al., 1988: 265, figs. 3A, 5F; Lynn and Gilron, 1993: 62, figs. 2C, 7C; Pettigrosso, 2003: 124, fig. 11; Suzuki and Ota, 2011: 150, figs. 13, 14.

Diagnosis. Body conical to rhombus-shaped; deep oral groove; prominent and numerous trichites, positioned above girdle portion; size $13-19 \mu \mathrm{m}$ in length and $7-10 \mu \mathrm{m}$ in width after protargol impregnation; anterior membranelles composed of 13-15 dikinetids; ventral membranelles distinctly separated from anterior membranelles, composed of 6-9 dikinetids; equatorial girdle kinety completely surrounding the cell, composed of 20-24 dikinetids; vertical ventral membranelles composed of 4-7 dikinetids; one inverted triangle-shaped macronucleus located at posterior of cell, $5 \times 4 \mu \mathrm{m}$ in size.

Morphological description of the Korean population. Body mostly conical to rhombus-shaped, long conical shape from several cells observed (Fig. 4D, E), truncated anterior portion and narrowed posterior portion, no apical protrusion detected (Fig. 4A-C). Small lip on anterior pole of ventral side (Fig. 4I). Trichites, prominent and numerous, but not in bundles, completely surrounding the girdle portion (Fig. $4 \mathrm{H}$, I). Slightly inflated distended cell surface from girdle portion to posterior end, no polygonal cell surface recognizable in protargol impregnated specimen. Size $13-19 \mu \mathrm{m}$ in length and $7-10 \mu \mathrm{m}$ in width after protargol impregnation (average $14.9 \times 9.2 \mu \mathrm{m}, \mathrm{n}=14)$. Cell length by width ratio, 1.4-2.2:1

Korean name: ${ }^{1 *}$ 횃불민소모충 

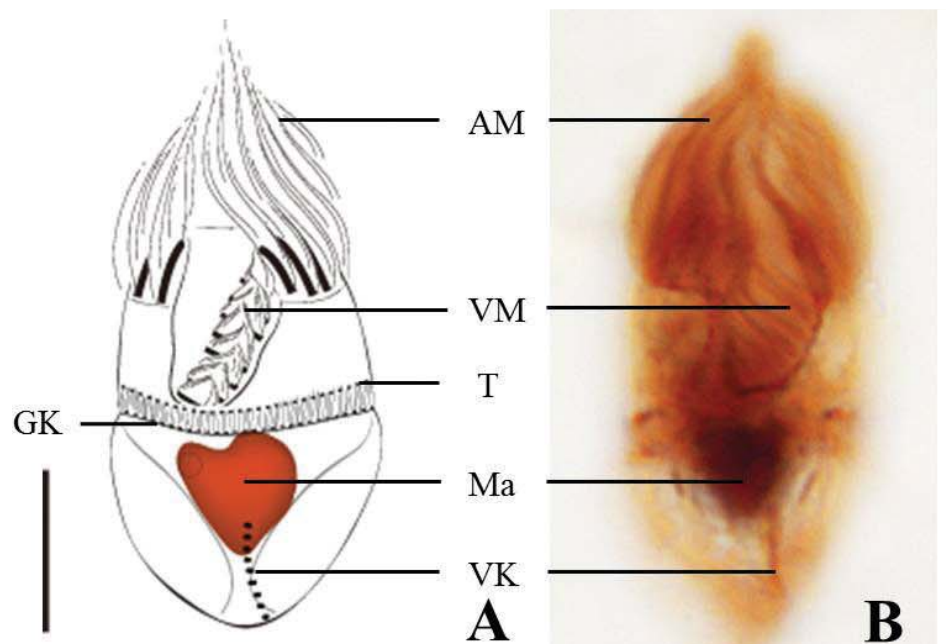

A
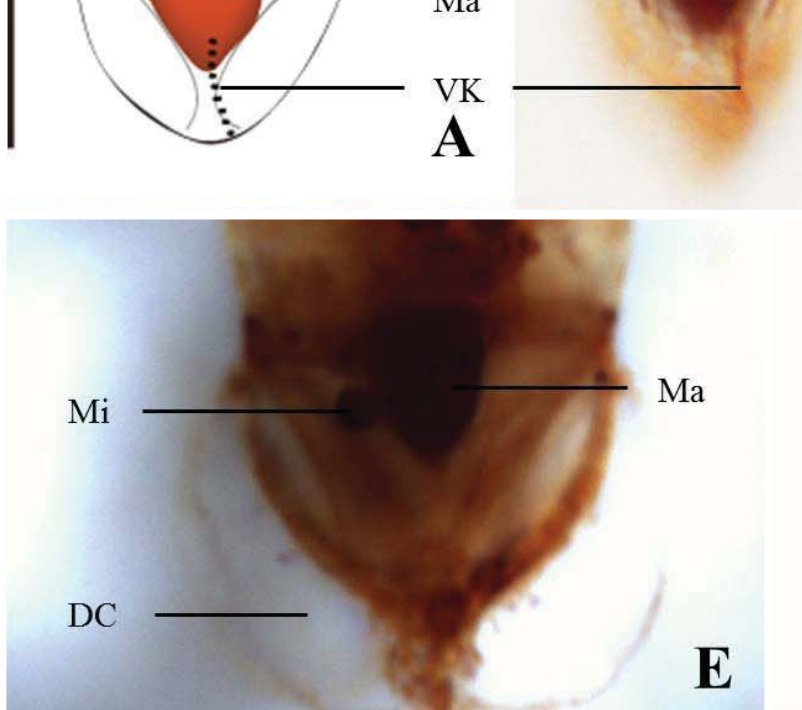

B
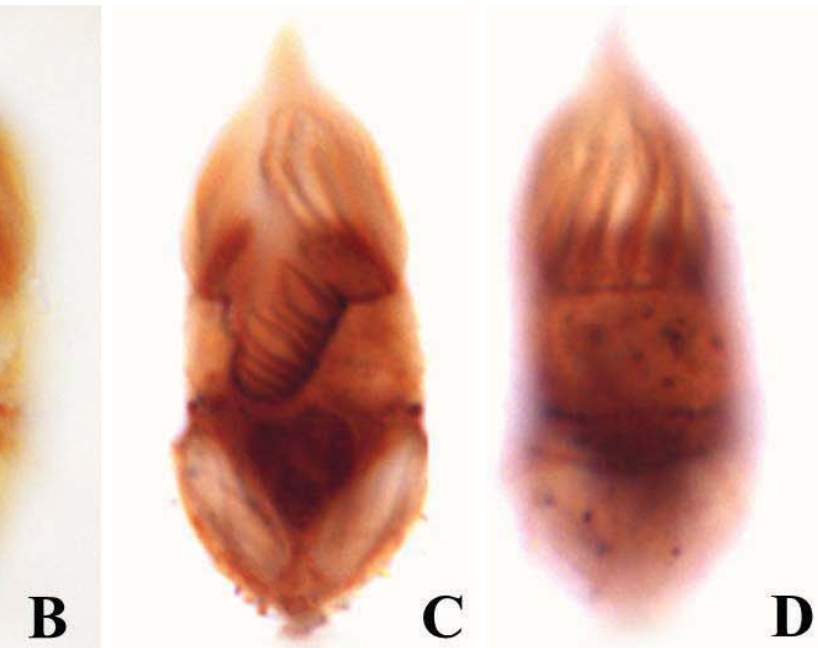

D

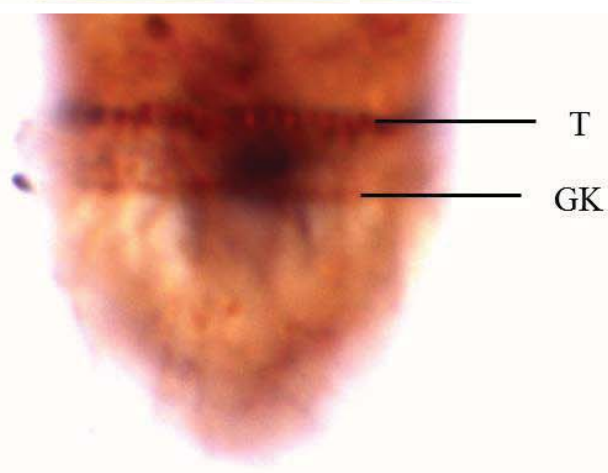

$\mathbf{F}$

Fig. 2. Strombidium emergens after protargol impregnation. A-C, Ventral view; D, Doral view; $E$, One macronucleus and one micronucleus; F, Trichites positioned above girdle kinety. AM, anterior membranelles; DC, distended cell surface; GK, girdle kinety; Ma, macronucleus; Mi, micronucleus; T, trichites; VK, ventral kinety; VM, ventral membranelles. Scale bars: $A, F=10 \mu \mathrm{m}$.

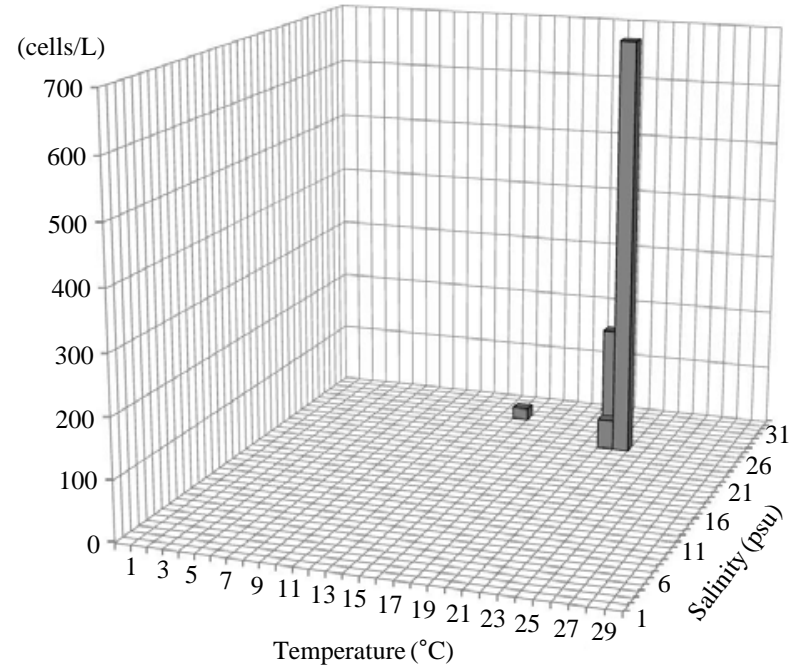

Fig. 3. Abundances of Strombidium emergens occurred at different temperatures $\left({ }^{\circ} \mathrm{C}\right.$ ) and salinities (psu). (average 1.6:1, $\mathrm{n}=14$ ).

Anterior membranelles distinctly separated from ventral membranelles. The cilia of anterior membranelles, long and spiral (usually torch-like shaped cilia), surrounding the anterior end of cell, composed of 13-15 polykinetids (average 14 polykinetids, $n=14$ ). Ventral membanelles lying on deep oral groove that forms a sunken pit, almost enclosed by left wall of oral groove, extending obliquely towards right side of cell and terminating one-third to half of the way down the cell, composed of 6-9 polykinetids (average 8 polykinetids, $\mathrm{n}=12$ ). No endoral membrane detected.

Somatic ciliature composed of girdle kinety and ventral kinety, no extra kinety detected. Girdle kinety, equatorial, completely surrounding, composed of 20-24 dikinetids (average 22 dikinetids, $n=4)$. Ventral kinety, vertically extended from posterior of cell, composed of 4-7 dikinetids (average 6 dikinetids, $\mathrm{n}=5$ ) (Fig. 4C, E).

One macronucleus, mostly inverted triangle shaped and 

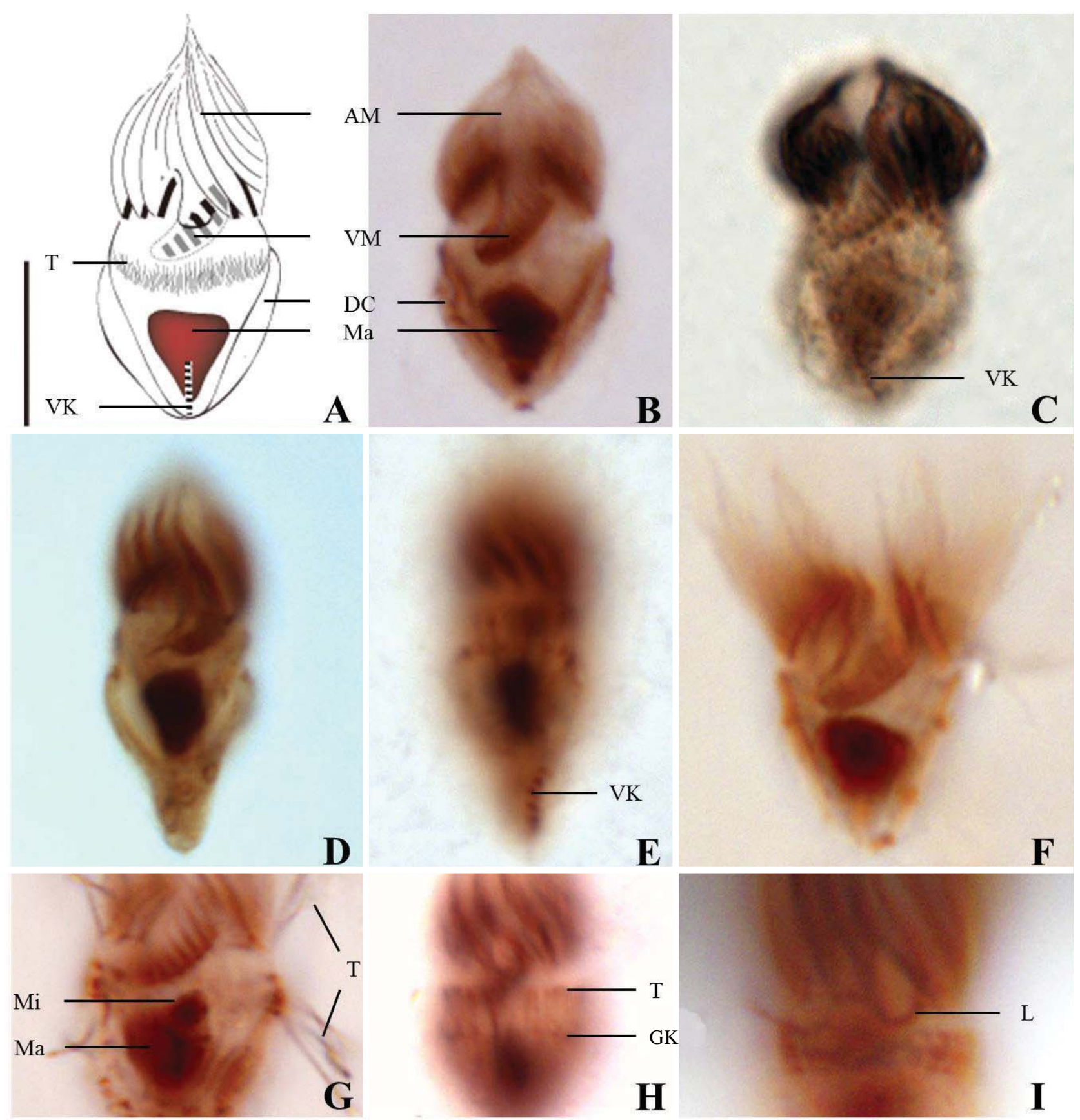

Fig. 4. Strombidim dalum after protargol impregnation. A-I, Ventral view; D, Several cells having long body shape; F, Not spiral cilia of anterior membranlles; G, Extruded trichites from the body; $\mathrm{H}$, Trichites positioned above girdle kinety; I, Small lip on oral region. AM, anterior membranelles; DC, distended cell surface; GK, girdle kinety; L, small lip; Ma, macronucleus; Mi, micronucleus; $\mathrm{T}$, trichites; VK, ventral kinety; VM, ventral membranelles. Sale bar: $A=10 \mu \mathrm{m}$.

located at posterior end, $4-6 \mu \mathrm{m}$ in length and $2-5 \mu \mathrm{m}$ in maximum width (average $4.7 \times 3.6 \mu \mathrm{m}, \mathrm{n}=12$ ). One spherical micronucleus, $1-2 \mu \mathrm{m}$ in diameter (average $1.3 \mu \mathrm{m}$ in diameter, $n=6$ ) (Fig. 4G).

Occurrence and ecological characteristics. The Korean population was collected from Jinhae Bay and Gwangyang Bay in all seasons (water temperature of $4-29^{\circ} \mathrm{C}$ and salinity of 9-34 psu). A maximum abundance (1,800 cells/L) was observed in Jinhae Bay in August, 2011 (water temperature of $22^{\circ} \mathrm{C}$ and salinity of 27 psu) (Fig. 5). 


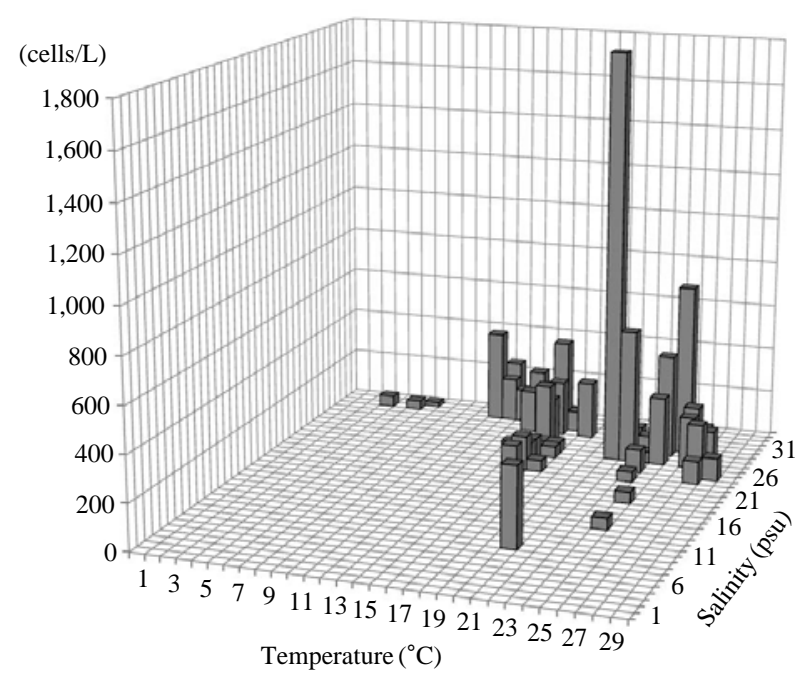

Fig. 5. Abundances of Strombidium dalum occurred at different temperatures $\left({ }^{\circ} \mathrm{C}\right)$ and salinities (psu).

The Argentina population was collected from Puerto Cuatreros in the lower temperature of $9-13^{\circ} \mathrm{C}$ and the salinity of 30-31 psu (Pettigrosso, 2003).

Comparison with other populations. According to original description by Lynn et al. (1988), the cilia of the anterior polykinetids in the Atlantic population have spiral torch-like anterior membranelles. Lynn and Gilron (1993) noted that it may be an artifact of fixing and staining. They observed both torch-like cilia of anterior membranlles and fan-like one from the Jamaican population. In the Korean population, we also observed the two types of anterior membranelles (Fig. $4 \mathrm{~F})$. There are no description of the ventral kinety in the Atlantic and the Argentina populations (Lynn et al., 1988; Lynn and Gilron, 1993). However, the Jamaica and the Korean populations appeared the ventral kinety ( 3 dikineds and 4-7 dikinetids repectively) (Pettigrosso, 2003). Recently, the Canadian population was recorded by Suzuki and Ota(2011). Compared with the Korean population, all morphometric data overlap except for macronucleus size (about $5 \times 4 \mu \mathrm{m}$ in the Korean population vs. $8 \times 6 \mu \mathrm{m}$ in the Canadian population).

${ }^{1 *}$ Strombidium epidemum Lynn et al., 1988 (Table 1, Figs. 6, 7)

Strombidium epidemum Lynn et al., 1988: 267, figs. 3B, 6A, B; Lynn and Gilron, 1993: 62, figs. 5A, 7A, B; Suzuki and Ota, 2011: 151, figs. 15, 16.

Diagnosis. Body truncate conical; size $12-20 \mu \mathrm{m}$ in length and $10-17 \mu \mathrm{m}$ in width after protargol impregnation; prominent trichites surrounding the cell; oral groove opened on ventral surface; anterior membranelles composed of 12-15 dikinetids; ventral membranelles separated from anterior membranelles, composed of 5-7 dikinetids; equatorial girdle kinety, surrounding the cell; one spherical to ovoid macronucleus, $6 \times 4 \mu \mathrm{m}$ in size; small Strombidium species $(\leq 20$ $\mu \mathrm{m})$.

Morphological description of the Korean population. Body truncate conical. Size $12-20 \mu \mathrm{m}$ in length and 10-17 $\mu \mathrm{m}$ in width (average $14.6 \times 12.0 \mu \mathrm{m}, \mathrm{n}=17$ ), cell length by width ratio, $1.2: 1.0$ after protargol impregnation. Prominent trichites inserting to anterior of girdle portion and extending internally toward posterior of body, 2-7 $\mu \mathrm{m}$ in length. A tiny globular drop on posterior end of cell, 1-2 $\mu \mathrm{m}$ in diameter (average $1.4 \mu \mathrm{m}$ in diameter, $\mathrm{n}=10$ ) (Fig. 6A, B).

Oral groove fairly opened on ventral surface of the cell. Anterior membranelles, equal length surrounding anterior end, composed of 12-15 polykinetids (average 14 polykinetids, $n=17)$. Ventral membranelles are distinctly separated from anterior membranlles and lie on a oral groove which occupies $1 / 2$ of cell length, to the posterior of ventral membranelles to posterior pole of cell distance 6-10 $\mu \mathrm{m}$ (average $7.9 \mu \mathrm{m}, \mathrm{n}=15$ ), composed of 5-7 polykinetids (average 6 polykinetids, $n=17$ ) (Figs. 6B, 12F). One to two polykinetids of ventral membranelles lying into oral cavity. No endoral membrane detected.

Somatic ciliature composed of girdle kinety and ventral kinetids, no extra kinety detected. Girdle kinety, equatorial, completely surrounding cell. Vertical ventral kinety with 4 dikinetids from posterior end of body.

One spherical to ovoid macronucleus, $4-11 \times 3-6 \mu \mathrm{m}$ (average $6.1 \times 4.2 \mu \mathrm{m}, \mathrm{n}=17$ ), positioned posterior. One micronucleus on macronucleus, $1-2 \mu \mathrm{m}$ in diameter (average $1.3 \mu \mathrm{m}$ in diameter, $\mathrm{n}=7$ ).

Opisthe (daughter cell) developing on right side of proter (Fig. 6C).

Occurrence and ecological characteristics. This species occurred from Jinhae Bay and Gwangyang Bay in all seasons (water temperature of $4-30^{\circ} \mathrm{C}$ and salinity of 2-34 psu). A maximum abundance $(2,075$ cells/L) of this species was observed in Jinhae Bay on May, 2011 (water temperature of $27^{\circ} \mathrm{C}$ and salinity of $27 \mathrm{psu}$ ) (Fig. 7).

Comparison with other populations. Strombidium epidemum was recorded from Gulf of Maine in 1988, Jamaica in 1993, and Canada in 2011 (not including ecological data). The Korean population is very similar to the Jamaican and the Canadian population in shape, body size, polykinetids number of anterior membranelles and ventral membranel-

Korean name: ${ }^{1 *}$ 범소민소모충(epidemos, Gr.-prevalent, 일반적인, 널리 퍼져있는) 

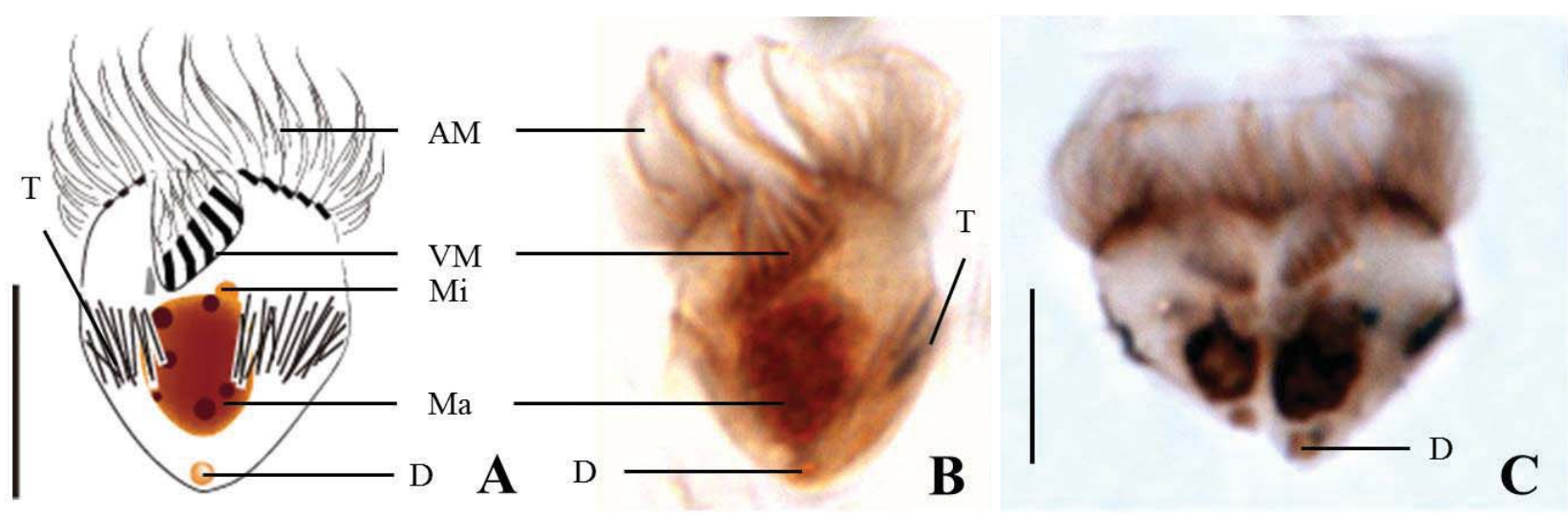

Fig. 6. Strombidium epidemum after protargol impregnation. A, B, Ventral view; C, Division of S. epidemum. AM, anterior membranelles; Ma, macronucleus; Mi, micronucleus; $\mathrm{D}$, a tiny globular drop at posterior end; $\mathrm{T}$, trichites; $\mathrm{VM}$, ventral membranelles. Sale bars: A, C=10 $\mu \mathrm{m}$.

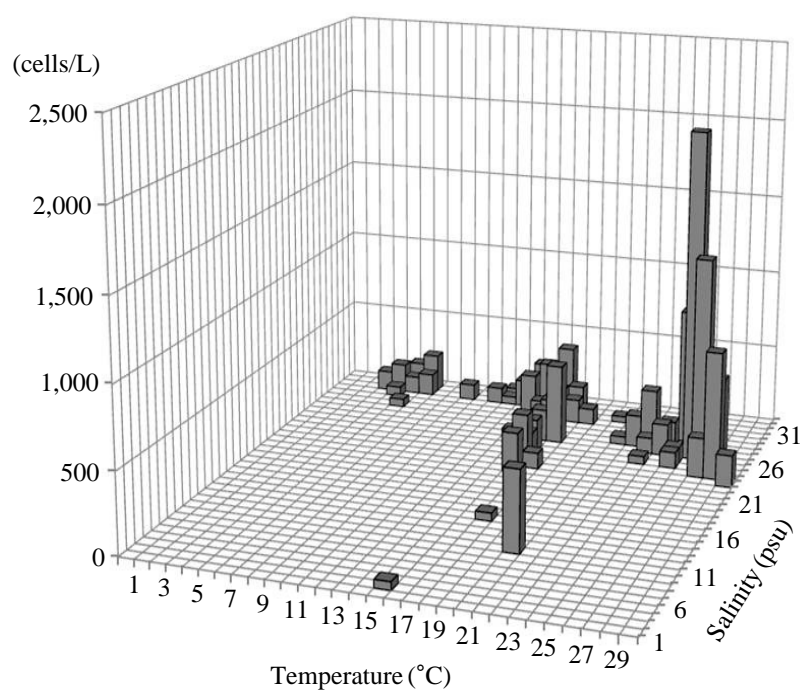

Fig. 7. Abundances of Strombidium epidemum occurred at different temperatures $\left({ }^{\circ} \mathrm{C}\right)$ and salinities (psu).

les, and ventral membranelles separated from anterior membranelles. However the Atlantic population has slightly smaller cell size than the Korean population (9-14 $\mu \mathrm{m}$ in length vs. 12-20 $\mu \mathrm{m}$ in length) (Lynn et al., 1988; Lynn and Gilron, 1993; Suzuki and Ota, 2011).

A tiny globular drop was positioned in the posterior end of S. epidemum cells collected from the bays in Korea. Strombidium dalum and $S$. pollostomum described as Korean populations in this study were also included the drop. Further observations need to understand its function and position inside the cell.

\section{${ }^{1 *}$ Strombidiuim tressum Lynn et al., 1988 (Table 1,}

Figs. 8, 9)

Strombidium tressum Lynn et al., 1988: 274, figs. 4F, 6H, I.

Diagnosis. Body ovoid to ellipsoidal; size 13-21 $\mu \mathrm{m}$ in length and $10-15 \mu \mathrm{m}$ in width after protargol impregnation; long trichites among cilia of anterior memnranelles; long and torchlike spiral anterior membranelles composed of 13-15 polykinetids; ventral membranelles composed of 5-8 polykinetids; supraequatorial girdle kinety composed of 30-38 dikinetids; vertical ventral kinety composed of 8-11 dikinetids; one ovoid macronucleus, $6 \times 4 \mu \mathrm{m}$ in size; one spherical micronucleus, about $1 \mu \mathrm{m}$ in diameter.

Morphological description of the Korean population. Body ovoid to ellipsoidal, relatively inflated distended cell surface from girdle portion to posterior pole, apical protrusion not found (Fig. 8A-C). Size 13-21 $\mu \mathrm{m}$ in length and 10$15 \mu \mathrm{m}$ in width (average $15.1 \times 12.4 \mu \mathrm{m}, \mathrm{n}=22$ ). Trichites locating above girdle kinety, but not extending internally toward posterior of body (Fig. 8E). The long trichites among cilia of anterior membranelles, spirally extending over full length of cell (Fig. 8B, D, E).

Anterior membranelles, as long as almost body length, spirally twisted cilia (torch-like), completely surrounding the cell, and composed of 13-15 polykinetids (average 15 polykinetids, $n=22$ ). Ventral membranelles enclosed by the ring of anterior membranelles, composed of 5-8 polykinetids (average 7 polykinetids, $n=18$ ) (Fig. $8 B, C$ ).

Somatic ciliature composed of girdle kinety and ventral kinety, no extra kinety detected. Girdle kinety, supraequatorial, completely surrounding the cell, composed of 30-38 dikinetids (average 33 dikinetids, $n=6$ ). Ventral kinety slight-

Korean name: ${ }^{1 *}$ 긴털민소모충 

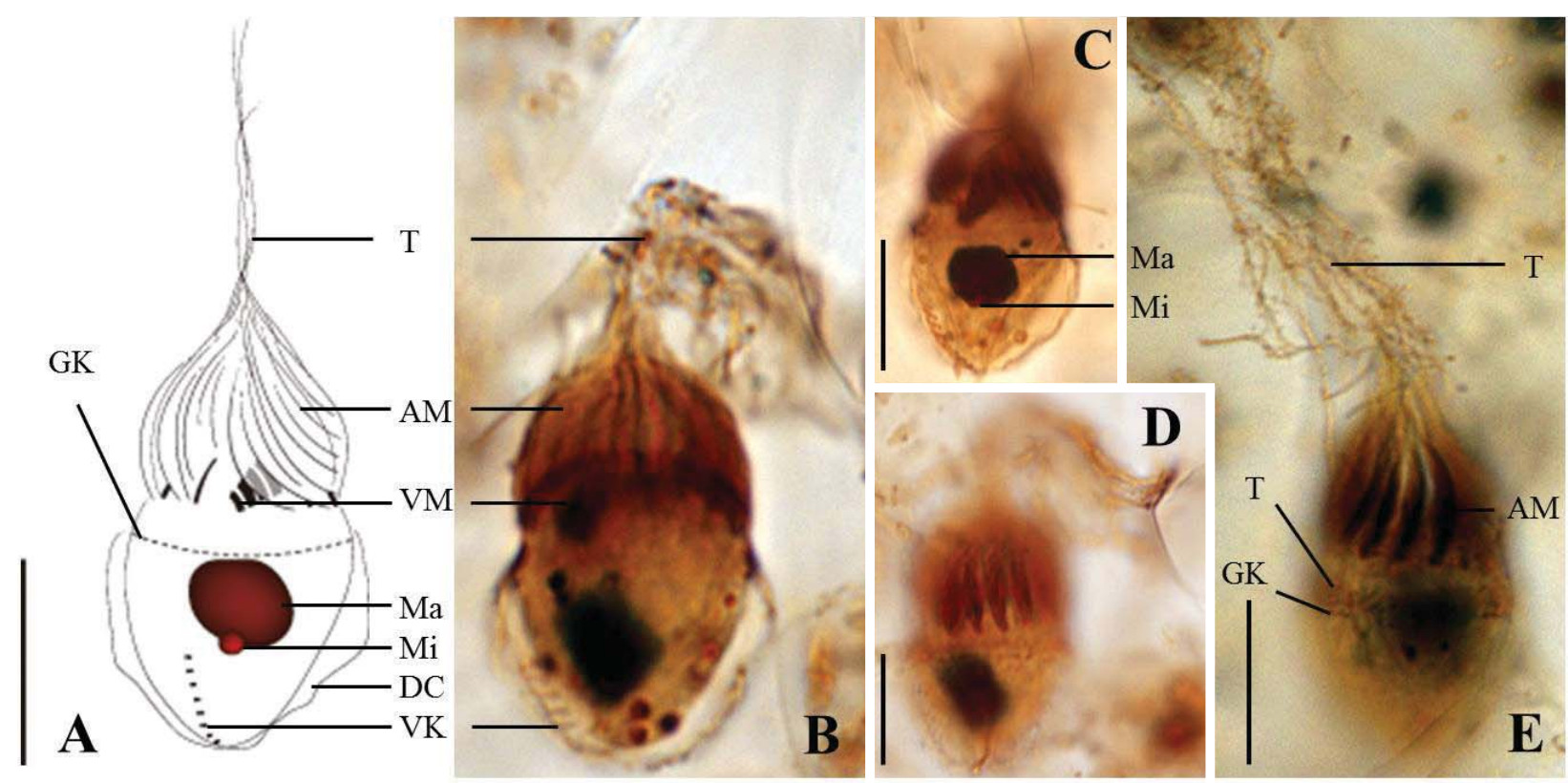

Fig. 8. Strombidim tressum after protargol impregnation. A-C, Ventral view; B, D, E, Long trichites among cilia of anterior membranelles. AM, anterior membranelles; DC, distended cell surface; GK, girdle kinety; Ma, macronucleus; Mi, micronucleus; $T$, trichites; VK, ventral kinety; VM, ventral membranelles. Scale bars: $A, C-E=10 \mu \mathrm{m}$.

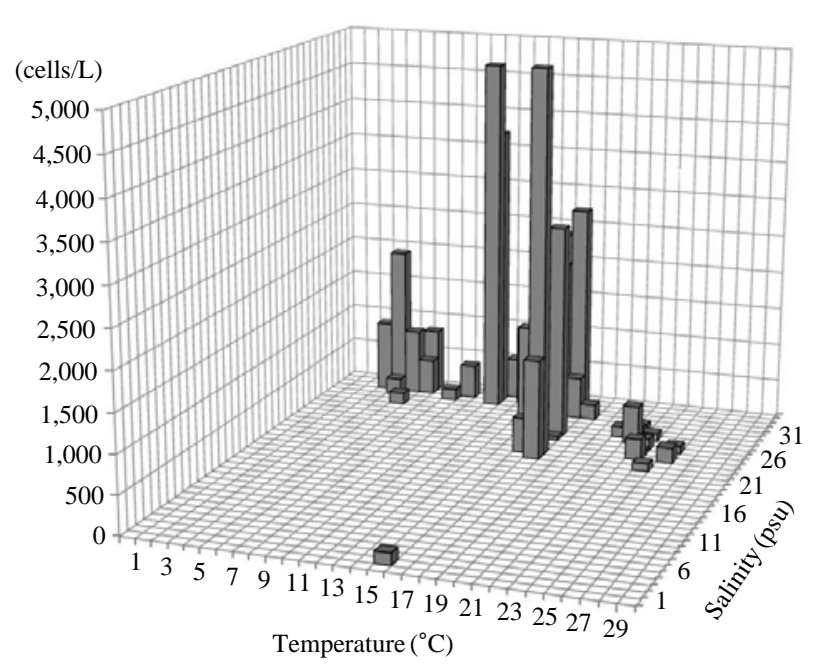

Fig. 9. Abundances of Strombidium tressum occurred at different temperatures $\left({ }^{\circ} \mathrm{C}\right)$ and salinities (psu).

ly slanted toward left, composed of 8-11 dikinetids on distended cell surface (average 9 dikinetids, $n=11$ ) (Fig. 8B).

One ovoid macronucleus, centrally positioned in cell, 5-7 $\mu \mathrm{m}$ in length and 1-6 $\mu \mathrm{m}$ in width (average $6.0 \times 4.6 \mu \mathrm{m}$, $\mathrm{n}=21$ ). One micronucleus on macronucleus, $1-2 \mu \mathrm{m}$ in diameter (average $1.0 \mu \mathrm{m}$ in diameter, $\mathrm{n}=4$ ) (Fig. 8C).
Occurrence and ecological characteristics. The Korean population was collected from Jinhae Bay and Gwangyang Bay in all seasons (water temperature of $4-26^{\circ} \mathrm{C}$ and salinity of 2-34 psu). A maximum abundance $(5,250$ cells/L) was observed in Jinhae Bay in May, 2011 (water temperature of $18^{\circ} \mathrm{C}$ and salinity of $23 \mathrm{psu}$ ) (Fig. 9).

Comparison with other population. According to the original description, the torch-like spiral anterior membranelles and the extremely long trichites among the cilia of anterior membranelles are unique characteristics in Strombidium tressum (Lynn et al., 1988). This population is smaller than original population $(13-21 \times 10-15 \mu \mathrm{m}$ in this population vs. $21-29 \times 13-19 \mu \mathrm{m}$ in original population). Moreover, the original population has an apical protrusion, but protrusion on anterior end is hardly observed in the Korean population.

\section{${ }^{1 *}$ Strombidium bilobum Lynn and Gilron, 1993 (Table 1, Figs. 10, 11)}

Strombidium bilobum Lynn and Gilron, 1993:50, figs. 1C, D, 2B.

Diagnosis. Body subconical with narrowed girdle area; size $31-36 \mu \mathrm{m}$ in length and $14-21 \mu \mathrm{m}$ in width after protargol impregnation; apical collar opened on ventral surface; anterior membranelles located on apical collar, composed of 14-17

Korean name: ${ }^{1 *}$ 아령핵민소모충 

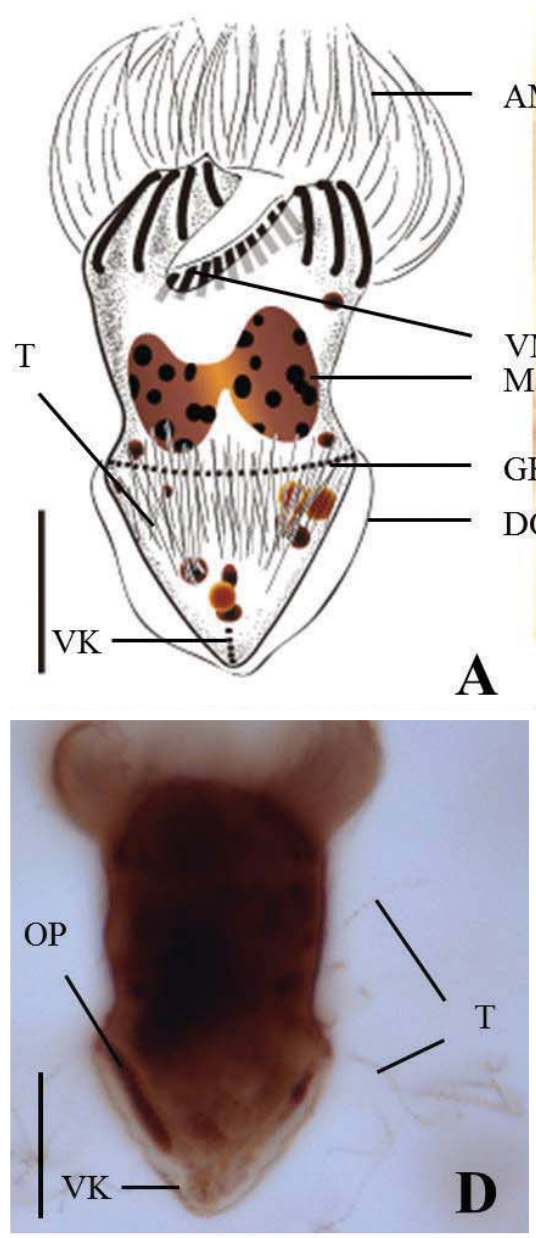
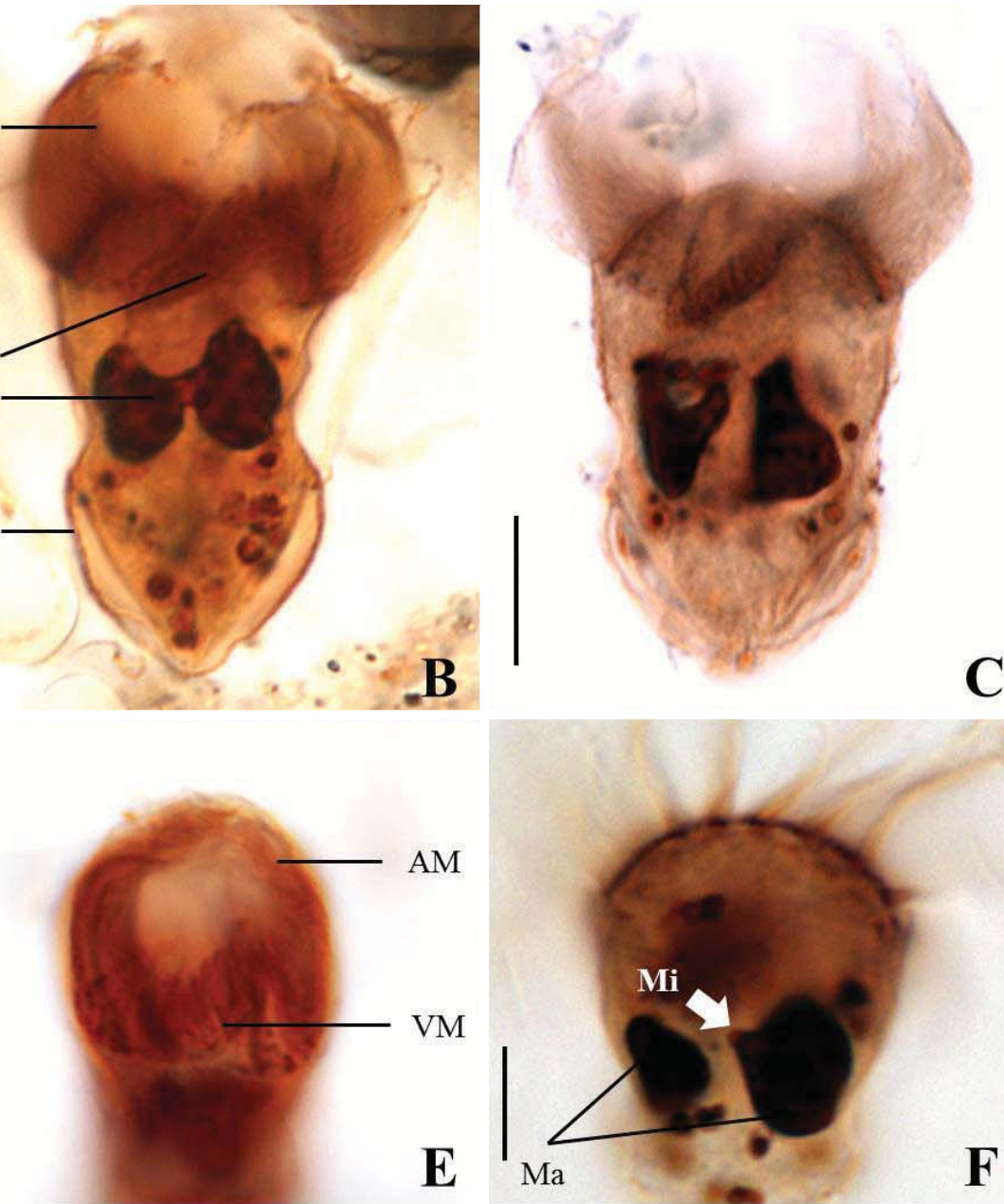

Fig. 10. Strombidium bilobum after protargol impregnation. A-C, Ventral view; $D$, Lateral view, oral primordium originated below girdle part and trichites extruded from body; $E$, Ventral membranelles almost covered by apical collar; F, Two macronuclear nodules. AM, anterior membranelles; DC, distended cell surface; GK, girdle kinety; Ma, macronucleus (or macronuclear nodules); $\mathrm{Mi}$, micronucleus; $\mathrm{OP}$, oral primordium; $\mathrm{T}$, trichites; VK, ventral kinety; VM, ventral membranelles. Scale bars: $A, C, D, F=10 \mu \mathrm{m}$.

polykinetids; ventral membranelles covered by apical collar, composed of 9-13 polykinetids; horizontal girdle kinety composed of 36-40 dikinetids; vertical ventral kinety composed of 4-6 dikinetids; two ovoid macronuclear nodules or dumbbell shaped macronucleus, about $8 \times 5 \mu \mathrm{m}$ in size.

Mophological description of the Korean population. Shape subconical, anterior cylindrical and posterior pointed, most cells slightly narrowed at girdle part (Fig. 10A-C). Size $31-36 \mu \mathrm{m}$ in length and $14-21 \mu \mathrm{m}$ in width (average $33.3 \times$ $17.8 \mu \mathrm{m}, \mathrm{n}=15$ ), cell length by width ratio about $2: 1$ after protargol impregnation. Trichites inserting on anterior of girdle kinety and internally extending posterior end of cell. Transparent distended cell surface expanded from girdle kinety to posterior of body (Fig. 10A, B).

Apical collar opened on ventral surface. Anterior membranelles surrounding apical collar and composed of 14-17 polykinetids (average 15 polykinetids, $n=11$ ). Ventral membranelles separated from anterior membranelles and obliquely lying on oral groove that extended into oral cavity and almost covered by the apical collar, composed of 9-13 polykinetids (average 11 polykinetids, $n=8$ ) (Fig. 10E). Distance from posterior end of ventral membranelles to posterior pole of cell about 21-27 $\mu \mathrm{m}$ (average $23.8 \mu \mathrm{m}, \mathrm{n}=15$ ).

Somatic ciliature composed of girdle kinety and ventral kinety, no extra kinety detected. Girdle kinety, subequatorial positioned (3/5 of body length), completely surrounding the cell, composed of 36-40 dikinetids. Distance from girdle kinety to posterior pole of cell distance 12-15 $\mu \mathrm{m}$ (average $13.2 \mu \mathrm{m}, \mathrm{n}=11$ ), Ventral kinety, vertically arranged from posterior pole of cell, composed of 4-6 dikinetids (average 5 dikinetids, $\mathrm{n}=9$ ) (Fig. 10A, D).

Two ovoid (separating) macronuclear nodules or dumb- 


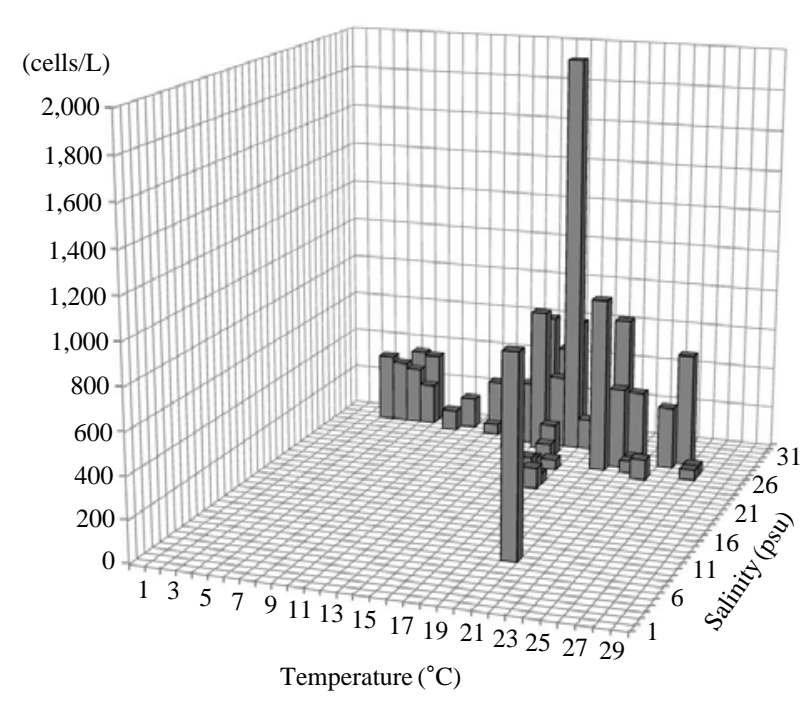

Fig. 11. Abundances of Strombidium bilobum occurred at different temperatures $\left({ }^{\circ} \mathrm{C}\right)$ and salinities (psu).

bell shaped (connecting with each other) macronucleus, positioned near the posterior margin of ventral membranelles, one size $6-11 \mu \mathrm{m}$ in length and $4-8 \mu \mathrm{m}$ in width, another size $7-11 \mu \mathrm{m}$ in length and $4-7 \mu \mathrm{m}$ in width (average $8.8 \times$ $4.9 \mu \mathrm{m}, 8.0 \times 5.0 \mu \mathrm{m}, \mathrm{n}=15)$ (Fig. 10B, C, F).

Oral primordium originated below girdle part and left portion of ventral side (Fig. 10D).

Occurrence and ecological characteristics. The Korean population was collected from Jinhae Bay and Gwangyang Bay in all seasons (water temperature of $4-27^{\circ} \mathrm{C}$ and salinity of 9-34 psu). The maximum abundance (1,950 cells/L) was observed in Jinhae Bay in May, 2011 (water temperature of $18^{\circ} \mathrm{C}$ and salinity of $31 \mathrm{psu}$ ) (Fig. 11).

Comparison with other population. Strombidium bilobum was first described from Kingston Harbour, Jamaica without any ecological data provided (Lynn and Gilron, 1993).

Compared with the Jamaican population, the Korean population has the similar shape, polykinetidal numbers, and bilobed macronucleus. However, there are two different morphological characteristics: the ventral membranelles are distinctly separated from anterior membranelles in the Korean population (vs. anterior membranelles continuous with the ventral membranelles in the Jamaica population) and subequatorial girdle kinety (vs. equatorial girdle kinety).

\section{1*Strombidium pollostomum Lynn and Gilron, 1993}

(Table 1, Figs. 12, 13)

Strombidium pollostomum Lynn and Gilron, 1993: 54, fig.

3C; Suzuki and Ota, 2011: 152, figs. 17, 18.
Diagnosis. Body hemisphere to semi-ovoid, posterior pointed; size $12-19 \mu \mathrm{m}$ in length and $8-15 \mu \mathrm{m}$ in width after protargol impregnation; oral groove opened on ventral surface of cell; anterior membranelles composed of 12-16 polykinetids; ventral membranelles continuous with anterior membranelles, composed of 4-6 polykinetids; subequatorial girdle kinety composed of 14-16 dikinetids; ventral kinety composed of 3-5 dikinetids; one spherical macronucleus, $6 \times 5 \mu \mathrm{m}$ in size; one micronucleus, about $1 \mu \mathrm{m}$ in diameter; small Strombidium species $(\leq 20 \mu \mathrm{m})$.

Morphological description of the Korean population. Hemisphere to semi-ovoid in body shape, posterior pointed (Fig. 12A-C, E). Cell size 12-19 $\mu \mathrm{m}$ in length and 8-15 $\mu \mathrm{m}$ in width (average $15.1 \times 10.7 \mu \mathrm{m}, \mathrm{n}=22$ ), cell length by width ratio=1.4: 1 after protargol impregnation. No trichites found in body. A tiny globular drop on posterior of cell, 1-2 in number and $1 \mu \mathrm{m}$ in diameter (average $1.1 \mu \mathrm{m}$ in diameter, $\mathrm{n}=10$ ) (Fig. 12A, B).

Oral groove opened on ventral surface of the cell. Anterior membranelles torch-like shaped and slightly sloped toward left side of cell, composed of 12-16 polykinetids (average 14 polykinetids, $n=19$ ). Ventral membranelles continuous with anterior membranelles, composed of 4-6 polykinetids (average 6 polykinetids, $n=19$ ), from posterior of ventral membranlles to posterior pole of cell distance $7-13 \mu \mathrm{m}$ (average $10.0 \mu \mathrm{m}, \mathrm{n}=18$ ) (Fig. 12B, C, E, G).

Somatic ciliature composed of girdle kinety and ventral kinety, no extra kinety detected. Girdle kinety, equatorial to subequatorial (1/2-1/3 from posterior end of cell), composed of 14-16 dikinetids (average 15 dikinetids, $n=2$ ), completely surrounding cell, from girdle kinety to posterior pole of cell distance 5-7 $\mu \mathrm{m}$ (average $6.1 \mu \mathrm{m}, \mathrm{n}=2$ ). Ventral kinety vertically extending from posterior end, composed of 3-5 dikinetids (average 4 dikinetids, $\mathrm{n}=8$ ) (Fig. 12D, E).

One spherical to ovoid macronucleus, containing many granules, 4-9 $\times 3-7 \mu \mathrm{m}$ (average $6.0 \times 4.9 \mu \mathrm{m}, \mathrm{n}=20$ ), positioned centrally. One micronucleus on macronucleus, $1 \mu \mathrm{m}$ in diameter (average $1.1 \mu \mathrm{m}$ in diameter, $\mathrm{n}=5$ ) (Fig. 12C).

Occurrence and ecological characteristics. This species was collected from Jinhae Bay and Gwangyang Bay in all seasons (water temperature of $4-28^{\circ} \mathrm{C}$ and salinity of 9-34 $\mathrm{psu})$. The maximum abundance $(1,550$ cells/L) of this species was observed in Jinhae Bay on May, 2011 (water temperature of $15^{\circ} \mathrm{C}$ and salinity of $31 \mathrm{psu}$ ) (Fig. 13).

Comparison with other population. Strombidium pollostomum was recorded from Jamaica in 1993, not including ecological data (Lynn and Gilron, 1993).

This species is very similar to the Jamaica population in shape, the continuous arrangement and polykinetid numbers

Korean name: ${ }^{1 *}$ 극소민소모충 

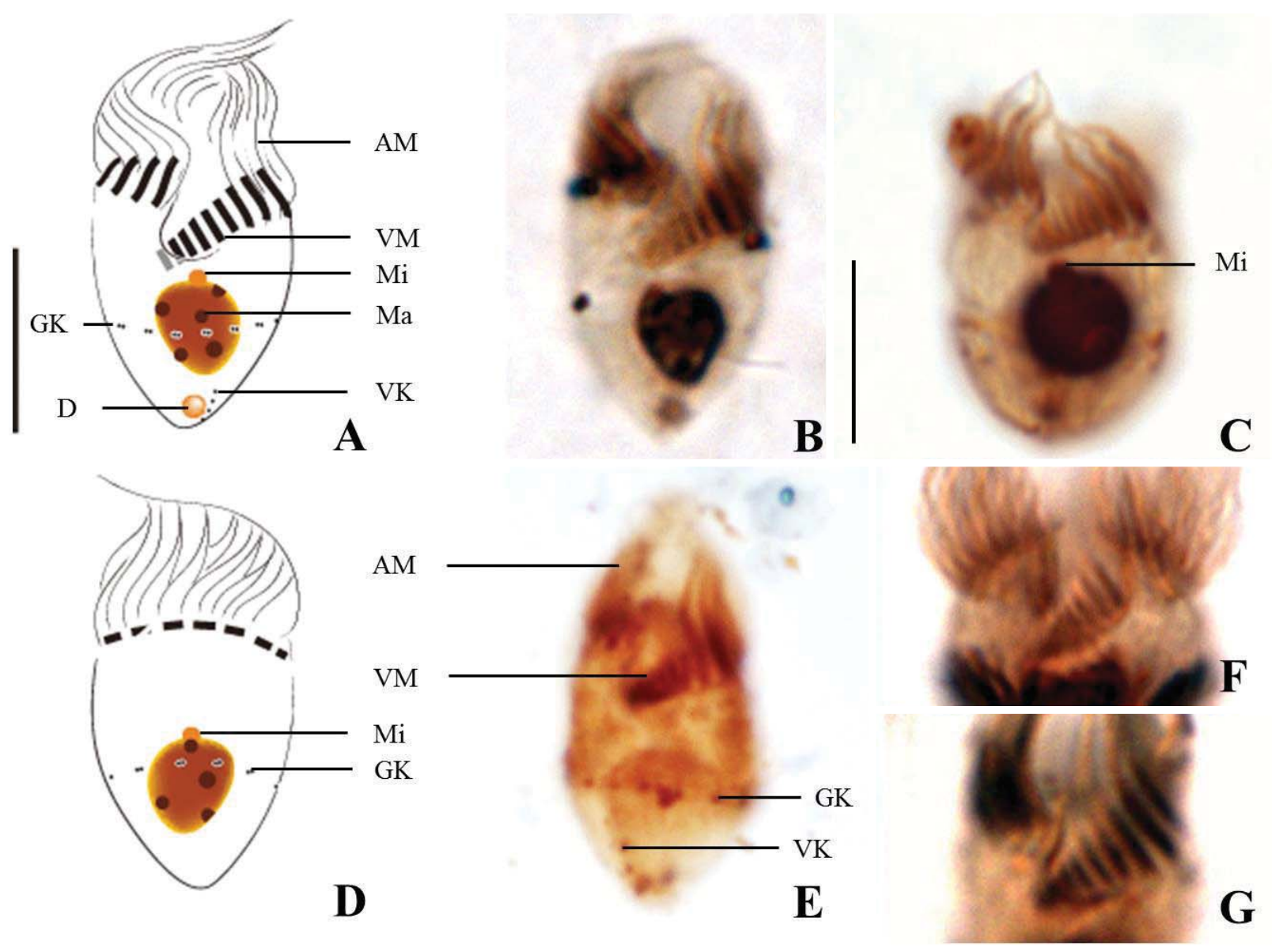

Fig. 12. Strombidium pollostomum after protargol impregnation. A-C, E, Ventral view; D, Dorsal view; $F$, Arrangement of oral membranelles from S. epidemum and G, from S. pollostomum. AM, anterior membranelles; GK, girdle kinety; Ma, macronucleus; Mi, micronucleus; D, a tiny globular drop at posterior end; VK, ventral kinety; VM, ventral membranelles. Scale bars: $A, C=10 \mu \mathrm{m}$.

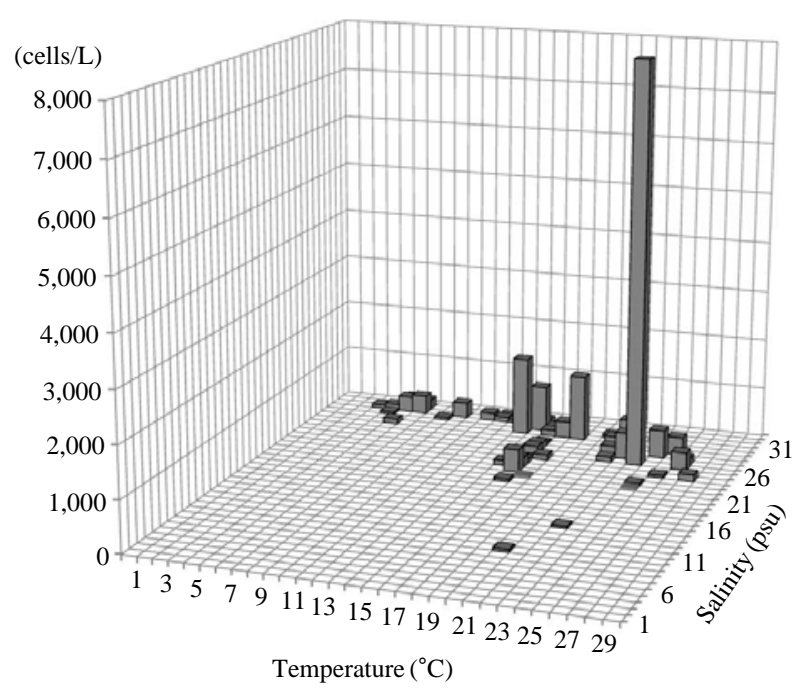

Fig. 13. Abundances of Strombidium pollostomum occurred at different temperatures $\left({ }^{\circ} \mathrm{C}\right)$ and salinities (psu). of anterior and ventral membranlles. However, the Korean population is bigger than the Jamaican population $(12-19 \times$ $8-15 \mu \mathrm{m}$ vs. $9-14 \times 7-11 \mu \mathrm{m})$ and has a globular drop on posterior of the cell.

Suzuki and Ota (2011) described a species under the name of Strombidium cf. inclinatum from Franklin Bay, Canada. Compared with $S$. inclinatum from original paper, $S$. cf. inclinatum has some differences that are not insignificant: fewer number of girdle kinety (14-15 dikinetids in $S$. cf. inclinatum vs. over 40 dikinetids in $S$. inclinatum) and ventral kinety (almost 2 dikinetids vs. 7-9 dikinetids), and the position of girdle kinety (posterior part in cell vs. almost equatorial) (Montagnes et al., 1990; Suzuki and Ota, 2011). We found the more similar species than $S$. inclinatum and suggested that $S$. cf. inclinatum might be $S$. pollostomum. Strombidium cf. inclinatum are very similar to $S$. pollostomum: ovoid cell shape, the number of anterior and ventral membranelles, ventral membranelles continuous with anterior 
membranelles, the minor girdle kinety positioned posterior part, and unrecognizable trichites (Lynn and Gilron, 1993).

\section{ACKNOWLEDGMENTS}

We would like to sincerely thank Dr. S. H. Baek and Mr. M. H. Son (KIOST) for their assistance in measuring environmental data and cooperation during the sampling. This study was supported by the grant from the Korea Institute of Ocean Science and Technology (PE98745; Y. O. Kim), the National Research Foundation of Korea Grant funded by the Korea Government (No. 2009-0077263) and "The Survey of Korean Indigenous Species" supported by the National Institute of Biological Resources (NIBR) of Korea.

\section{REFERENCES}

Agatha S, 2003. Morphology and ontogenesis of Novistrombidium apsheronicum nov. comb. and Strombidium arenicola (Protozoa, Ciliophora): a comparative light microscopical and SEM study. European Journal of Protistology, 39:245266.

Agatha S, 2004a. A cladistic approach for the classification of oligotrichid ciliates (Ciliophora: Spirotricha). Acta Protozoologica, 43:201-217.

Agatha S, 2004b. Evolution of ciliary patterns in the Oligotrichida (Ciliophora, Spirotricha) and its taxonomic implications. Zoology (Jena), 107:153-168.

Agatha S, 2011. Updated hypothesis on the evolution of oligotrichid ciliates (Ciliophora, Spirotricha, Oligotrichida) based on somatic ciliary patterns and ontogenetic data. European Journal of Protistology, 47:51-56.

Agatha S, Riedel-Lorjé JC, 1997. Morphology, infraciliature, and ecology of Halteriids and Strombidiids (Ciliophora, Oligotrichea) from coastal brackish water basins. Archiv für Protistenkunde, 148:445-459.

Agatha S, Strüder-Kypke MC, 2007. Phylogeny of the order Choreotrichida (Ciliophora, Spirotricha, Oligotrichea) as inferred from morphology, ultrastructure, ontogenesis, and SSrRNA gene sequences. European Journal of Protistology, 43:37-63.

Agatha S, Strüder-Kypke MC, Beran A, Lynn DH, 2005. Pelagostrobilidium neptuni (Montagnes and Taylor, 1994) and Strombidium biarmatum nov. spec. (Ciliophora, Oligotrichea): phylogenetic position inferred from morphology, ontogenesis, and gene sequence data. European Journal of Protistology, 41:65-83.

Bojaníc N, Vidjak O, Brautović I, 2006. Spatial and temporal variability in abundance and biomass of oligotrich ciliates in Kaštela Bay (middle Adriatic Sea). Acta Adriatica, 47:93-
109.

Fauré-Fremiet E, 1932. Strombidium calkinsi, a new thigmotactic species. The Biological Bulletin, 62:201-204.

Fileman ES, Leakey RJG, 2005. Microzooplankton dynamics during the development of the spring bloom in the north-east Atlantic. Journal of the Marine Biological Association of the United Kingdom, 85:741-753.

Granda AP, Montagnes DJS, 2003. An improved description of Stormbidium sulcatum Claparède \& Lachmann, 1859 (Ciliophora) from slides of Fauré-Fremiet, and a designation of type material. The Journal of Eukaryotic Microbiology, 50: 422-426.

Jeong HJ, Kim JS, Kim S, Song JY, Lee I, Lee GH, 2004. Strombidinopsis jeokjo $\mathrm{n}$. sp. (Ciliophora: Choreotrichida) from the coastal waters off western Korea: morphology and small subunit ribosomal DNA gene sequence. The Journal of Eukaryotic Microbiology, 51:451-455.

Kahl A, 1932. Urtiereoder Protozoa I: Wimpertiereoder Ciliata (Infusoria). 3. Spirotricha. Die Tierwelt Deutschlands, 25: 399-650.

Kim JS, Jeong HJ, Strüder-Kypke MC, Lynn DH, Kim S, Kim JH, Lee SH, 2005. Parastrombidinopsis shimi n. gen., n. sp. (Ciliophora: Choreotrichia) from the coastal waters of Korea: morphology and small subunit ribosomal DNA sequence. The Journal of Eukaryotic Microbiology, 52:514-522.

Kim YO, Ha S, Taniguchi A, 2008. Morphology and in situ sedimentation of the cysts of a planktonic oligotrich ciliate, Strombidium capitatum. Aquatic Microbial Ecology, 53:173-179.

Kim YO, Kim SY, Lee WJ, Choi JK, 2010. New observations on the choreotrich ciliates Strombidinopsis acuminata FauréFremiet 1924, and comparison with Strombidinopsis jeokjo Jeong et al., 2004. The Journal of Eukaryotic Microbiology, 57:48-55.

Kim YO, Taniguchi A, 1997. Seasonal variation of excystment pattern of the planktonic oligotrich ciliate Strombidium conicum. Marine Biology, 128:207-212.

Lee ES, Shin MK, Kim YO, 2011. Morphological descriptions of four oligotrich ciliates (Ciliophora: Oligotrichia) from southern coast of Korea. Korean Journal of Systematic Zoology, 27:131-141.

Lee KC, Choi JK, Kim SY, Yang EJ, 2006. First record of two marine planktonic ciliates Rimostrombidium orientale and $R$. veniliae (Ciliophora: Choreotrichida) from Korea. Korean Journal of Systematic Zoology, 22:217-221.

Leegaard C, 1915. Untersuchungen über einige planktonciliaten des Meeres. Nytt magazin for naturvidenskaberne, 53:137.

Lei Y, Xu K, Song W, 1999. Morphological studies on a new ciliate, Heterostrombidium paracalkinsi nov. spec. from mariculture water (Ciliophora, Oligotrichida). Chinese Journal of Applied and Environmental Biology, 5:181-184.

Liu W, Yi Z, Lin X, Al-Rasheid KAS, 2011. Morphologic and molecular data suggest that Lynnella semiglobulosa n. g., n. sp. represents a new family within the subclass Choreo- 
trichia (Ciliophora, Spirotrichea). The Journal of Eukaryotic Microbiology, 58:43-49.

Lynn DH, Gilron GL, 1993. Strombidiid ciliates from coastal waters near Kingston Harbour, Jamaica (Ciliophora, Oligotrichia, Strombidiidae). Journal of the Marine Biological Association of the United Kingdom, 73:47-65.

Lynn DH, Montagnes DJS, Small EB, 1988. Taxonomic descriptions of some conspicuous species in the family Strombidiidae (Ciliophora: Oligotrichida) from the Isles of Shoals, Gulf of Maine. Journal of the Marine Biological Association of the United Kingdom, 68:259-276.

Ma H, Choi JK, 2005. Morphogenesis of marine ciliate Pelagostrobilidium (Ciliophora: Oligotrichia). Korean Journal of Systematic Zoology, 21:21-30.

Maeda M, 1986. An illustrated guide to the species of the families Halteriidae and Strobilidiidae (Oligotrichida, Ciliophora), free swimming protozoa common in the aquatic environment. Bulletin of the Ocean Research Institute, University of Tokyo, 21:1-67.

Maeda M, Carey PG, 1985. An illustrated guide to the species of the family Strombidiidae (Oligotrichida, Ciliophora), free swimming protozoa common in the aquatic environment. Bulletin of the Ocean Research Institute, University of Tokyo, 19:1-68.

Martin AJ, Montagnes DJS, 1993. Winter ciliates in a British Columbian Fjord: six new species and an analysis of ciliate putative prey. The Journal of Eukaryotic Microbiology, 40: 535-549.

McManus GB, Xu D, Costas BA, Katz LA, 2010. Genetic identities of cryptic species in the Strombidium stylifer/apolatum/ oculatum cluster, including a description of Strombidium rassoulzadegani $\mathrm{n}$. sp. The Journal of Eukaryotic Microbiology, 57:369-378.

Modeo L, Petroni G, Rosati G, Montagnes DJS, 2003. A multidisciplinary approach to describe protists: redescriptions of Novistrombidium testaceum Anigstein 1914 and Strombidium inclinatum Montagnes, Taylor, and Lynn 1990 (Ciliophora, Oligotrichida). The Journal of Eukaryotic Microbiology, 50:175-189.

Montagnes DJS, Humphrey E, 1998. A description of occurrence and morphology of a new species of red-water forming Strombidium (Spirotrichea, Oligotrichia). The Journal of Eukaryotic Microbiology, 45:502-506.

Montagnes DJS, Lowe CD, Poulton A, Jonsson PR, 2002. Redescription of Strombidium oculatum Gruber 1884 (Ciliophora, Oligotrichia). The Journal of Eukaryotic Microbiology, 49:329-337.

Montagnes DJS, Lynn DH, 1991. Taxonomy of choreotrichs, the major marine planktonic ciliates, with emphasis on the aloricate forms. Marine Microbial Food Webs, 5:59-74.

Montagnes DJS, Lynn DH, 1993. A quantitative protargol stain (QPS) for ciliates and other protists. In: Handbook of methods in aquatic microbial ecology (Eds., Kemp PF, Sherr BF, Sherr EB, Cole JJ). Lewis Publishers, Boca Raton, FL, pp. 229-240.

Montagnes DJS, Lynn DH, Stoecker DK, Small EB, 1988. Taxonomic descriptions of one new species and redescription of four species in the family Strombidiidae (Ciliophora, Oligotrichida). Journal of Protozoology, 35:189-197.

Montagnes DJS, Taylor FJR, Lynn DH, 1990. Strombidium inclinatum n. sp. and a reassessment of Strombidium sulcatum Claparède and Lachmann (Ciliophora). Journal of Protozoology, 37:318-323.

Moon EY, Kim YO, Kim BH, Kong DS, Han MS, 2004. Taxonomic and ecologic studies on ciliate plankton in Pal'tang reservoir, Korea. Korean Journal of Limnology, 37:149-179.

Pettigrosso RE, 2003. Planktonic ciliates Choreotrichida and Strombidiida from the inner zone of Bahía Blanca Estuary, Argentina. Iheringia, Série Zoologia, 93:117-126.

Petz W, Foissner W, 1992. Morphology and morphogenesis of Strobilidium caudatum (Fromentel), Meseres corlissi n. sp., Halteria grandinella (Müller), and Strombidium rehwaldi $\mathrm{n}$. sp., and a proposed phylogenetic system for oligotrich ciliates (Protozoa, Ciliophora). The Journal of Eukaryotic Microbiology, 39:159-176.

Petz W, Song W, Wilbert N, 1995. Taxonomy and ecology of the ciliates fauna (Protozoa, Ciliophora) in the endopagial and pelagial of the Weddell Sea, Antarctica. Stapfia, 40:1223.

Quevedo M, Anadón R, 2000. Spring microzooplankton composition, biomass and potential grazing in the central Cantabrian coast (south Bay of Biscay). Oceanologica Acta, 23: 297-309.

Song W, Bradbury PC, 1998. Studies on some new and rare reported marine planktonic ciliates (Ciliophora: Oligotrichia) from coastal waters in north China. Journal of the Marine Biological Association of the United Kingdom, 78: 767794.

Song W, Wang M, Warren A, 2000. Redescriptions of three marine ciliates, Strombidium elegans Florentin, 1901, Strombidium sulcatum Claparède \& Lachmann, 1859 and Heterostrombidium paracalkinsi Lei, Xu \& Song, 1999 (Ciliophora, Oligotrichida). European Journal of Protistology, 36: 327-342.

Suzuki T, Han MS, 2000. A study on a new species of Tontonia (Ciliophora: Oligotrichida) from the East China Sea and adjacent sea areas. Journal of the Marine Biological Association of the United Kingdom, 80:989-994.

Suzuki T, Ota T, 2011. Planktonic ciliates below sea ice in Franklin Bay, Canada. Plankton and Benthos Research, 6:141157.

Xu D, Song W, Warren A, 2006. Morphology and infraciliature of two new species of marine oligotrich ciliates (Ciliophora: Oligotrichida) from China. Journal of Natural History, 40:1287-1299.

Xu D, Song W, Warren A, Roberts D, Hu X, 2007. Redescriptions of two marine planktonic ciliates from China, Parastrombidium faurei (Kahl, 1932) Maeda, 1986 and Strom- 
bidium capitatum (Leegaard, 1915) Kahl, 1932 (Ciliophora, Oligotrichea). European Journal of Protistology, 43:27-35.

Xu D, Warren A, Song W, 2009. Oligotrichs. In: Free-living ciliates in the Bohai and Yellow Seas, China (Eds., Song
W, Warren A, Hu X). Science Press, Beijing, pp. 308-322.

Received June 11, 2012

Revised July 18, 2012

Accepted July 20, 2012 